\title{
РОЛЬ МЕДИЧНОЇ СЕСТРИ У НАВЧАННІ ХВОРИХ ПО ДОГЛЯДУ ЗА ДІАБЕТИЧНИМИ СТОПАМИ
}

\author{
І. О. Беркела, Л. В. Наумова \\ ДВНЗ «Тернопільський державний медичний університет \\ імені І. Я. Горбачевського МОЗ Украӥни»
}

У статті наведено дані щодо необхідності проведення навчання хворих із діабетичною стопою з метою кращої компенсації цукрового діабету. Доведено, що правильний догляд за стопами дозволяє сповільнити прогресування мікросудинних уражень при цукровому діабеті та скоротити час перебування пацієнта в стаціонарі.

\section{THE ROLE OF THE NURSE IN TRAINING OF PATIENTS TO CARE FOR DIABETIC FOOT}

\section{O. Berkela, L. V. Naumova}

\section{Horbachevsky Ternopil State Medical University}

\begin{abstract}
The article presents data on the need for training the patients with diabetic foot to do better compensation of type 2 diabetes. To sum up, the proper care of feet allow to slow the progression of microvascular lesions in diabetes mellitus type 2 and reduce the patients' stay in hospital.
\end{abstract}

Вступ. Велика і значима роль медичної сестри в профілактиці багатьох захворювань. Саме медична сестра проводить біля пацієнта більшу частину свого часу і має право та зобов'язана доносити знання про профілактику захворювань різних органів та систем. На сьогодні вже не викликає сумніву той факт, що для ефективного лікування діабету потрібні спільні зусилля медичного працівника і пацієнта. Це можливо лише в тому випадку, коли пацієнти відповідним чином ознайомлені та виконують основні принципи постійного самоконтролю за хворобою.

Досвід деяких країн (США, Канади, Німеччини) вказує на те, що навчання хворих $є$ обов'язковою та інтегральною частиною лікування цукрового діабету (ЦД) [7]. Статистичні дані свідчать, що кваліфіковане навчання пацієнтів принципам самоконтролю захворювання сприяє зниженню кількості госпіталізацій та тяжких ускладнень із приводу ЦД у декілька разів. На сьогодні $\epsilon$ всі умови для успішного досягнення хворим оптимального рівня глікемії: індивідуальні глюкометри різних типів, інсулінові помпи тощо. ВООЗ офіційно визнала навчання повноправним методом лікування хронічних захворювань, рівнозначним медикаментозному та хірургічному. Було введено термін «терапевтичне навчання пацієнтів» [5], яке надає пацієнту можливість оволодіти вміннями, що (ㄱ. І. О. Беркела, Л. В. Наумова, 2017 дозволяють оптимально керувати своїм життям при захворюванні на ЦД $[1,3,4]$. Це $\epsilon$ безперервний процес, який має бути інтегрованим у систему медичної допомоги, сконцентрованим на пацієнтові та включати інформацію щодо навчання «самоконтролю» та психологічної підтримки хворого $[2,6]$.

Основна частина. Метою навчання хворих на цукровий діабет $\epsilon$ не заповнення вакууму знань хворих, а прогресивна зміна їх уявлення про захворювання і його наслідки, що приводить до зміни поведінки та до сформованого вміння управляти цукровим діабетом. Саме медичній сестрі належить важлива роль у навчанні пацієнта з синдромом діабетичної стопи щодо правильного догляду за стопами.

Навчаючись у школі діабетика пацієнти оволодівають наступними нехитрими прийомами по догляду за ногами: при щоденному митті ніг, їх потрібно витирати насухо, особливу увагу приділяючи ділянкам між пальцями; необхідно використовувати м'яке мило, користуватися теплою водою, добре висушувати свою шкіру, не терти; після миття потрібно використовувати лосьйон для стоп, щоб запобігти утворенню тріщин; не втирати лосьйон між пальцями ніг; щодня необхідно оглядати стопи. Ось рекомендації, які надає медична сестра пацієнту з синдромом діабетичної стопи:

- оглядайте ступні зверху та знизу. Попросіть когось зробити це, якщо Ви самі не можете їх побачити; 
- слідкуйте за появою сухої, потрісканої шкіри;

- шукайте пухирі, порізи, подряпини або виразки;

- перевіряйте на предмет почервоніння, місцевого підвищення температури або болючості при дотику до будь-якого місця на ступні;

- слідкуйте за нігтями, що вросли, а також мозолями;

- якщо у Вас на стопі пухир або виразка, не відкривайте їх. Скористайтеся пластиром і надіньте іншу пару взуття.

Будьте уважні під час виконання фізичних вправ: здійснюйте піші прогулянки і займайтеся фізичними вправами у зручному взутті, не займайтеся фізичними вправами, якщо на Ваших ступнях є відкриті рани, ніколи не ходіть босоніж. Завжди захищайте свої ступні за допомогою туфель або тапочок на твердій підошві, уникайте взуття на високих підборах і туфель з гострими носами та яке відкриває Ваші пальці або п'яти (наприклад, туфель з відкритими носами або сандалій). Ці види взуття підвищують Ваш ризик травми і потенційного інфікування. Не носіть тугих шкарпеток. Носіть шкарпетки з натуральних волокон (бавовна, шерсть або бавовняно-вовняна суміш). Переконайтеся, що взуття підходить Вам за розміром. якщо у Вас нейропатія (пошкодження нервів), Ви можете не помітити, що взуття занадто тісне. Проведіть «взуттєвий тест», описаний нижче.

Взуттєвий тест

Скористайтеся цим простим тестом, щоб переконатися, що взуття Вам підходить добре:

- станьте на лист паперу (переконайтеся, що ви стоїте, а не сидите, тому що при стоянні Ваші стопи змінюють форму);

- обведіть контур Вашої стопи;

\section{СПИСОК ЛІТЕРАТУРИ}

1. Гайтона А. К. Медична фізіологія / А. К. Гайтона, Дж. Е. Холл ; [пер. з англ.]. - М. : Логосфера, 2008. - 1296 с.

2. Дедов И. И. Сахарный диабет - опаснейший вызов мировому сообществу / И. И. Дедов // Вестник РАМН. 2012. - № 1. - C. 7-13.

3. Кудрина Т. В. Организационно-функциональная модель сестринской службы учреждений восстановительного лечения в современных условиях : автореф. на соиск. уч. степени дис. канд. мед. наук : 14.00.33 / Т. В. Кудрина. - Иваново, 2007. - 19 с.

4. Манерова О. А. Кадровая политика в здравоохранении от традиционного управления кадрами к управлению человеческими ресурсами / О. А. Манерова //
- обведіть контур ваших туфель;

- порівняйте ці відбитки: Чи не занадто взуття вузьке? Чи можете Ви взути туфлі? Взуття має бути довшим хоча 6 на сантиметр, ніж найдовший Ваш палець, а також ширшим, ніж Ваша стопа.

\section{Правильний вибір взуття}

Такі види взуття найкраще підходять для людей 3 цукровим діабетом:

- шкіряне взуття без швів всередині;

- із закритими носками та п'ятами, воно має бути принаймі на сантиметр довшим, ніж Ваш найдовший палець;

- усередині взуття має бути м'яким й не мати нерівностей;

- підошва повинна бути зроблена з жорсткого матеріалу;

- взуття має бути, принаймні, таке ж широке, як Ваша стопа.

Щоб ноги були здоровими необхідно контролювати рівень цукру в крові, щонайменше, 1 раз на 2 місяці; регулярно проводити обстеження у лікаря 3 метою виявлення ускладнень, що починаються (зміна больової, вібраційної, тактильної та температурної чутливості нижніх кінцівок); суворо дотримуватися правил догляду за ногами; вчасно проводити лікування ускладнень, що виникли.

Висновки. При догляді за хворими з синдромом діабетичної стопи, велике значення має щоденний догляд за стопами. Навчання у школі діабетика дозволяє пацієнтам краще зрозуміти і оволодіти основними навичками по догляду за стопами. Правильний догляд за стопами не лише може сповільнити прогресування судинних уражень, а й запобігти інвалідизації пацієнтів.

Проблемы управления здравоохранением. - 2004. № 7. - С. 66-69.

5. Удосконалення навчанню самоконтролю хворих на цукровий діабет: практика контролю компенсації хвороби та її ускладнень у дітей і підлітків / В. А. Музь, Н. М. Музь, О. В. Антропова [та ін.] // Ендокринологія. 2013. - T. 18, № 3. - С. 64-69.

6. Отдаленные результаты терапевтического обучения больных сахарным диабетом типа 1 / Г. Р. Галстян, А. Ю. Майоров, О. М. Двойнишникова и др. // Проблемы эндокринологии. - 2005. - Т. 51, № 3. - С. 50-55.

7. Фадеев П. А. Сахарный диабет. Доступно и достоверно / П. А. Фадеев. - М. : Оникс, 2009. - 208 с. 